\title{
A SUSPENSÃO DA PRESCRIÇÃO DA PRETENSÃO PUNITIVA NOS TRIBUNAIS DE CONTAS PELA LEI DA COVID-19
}

\author{
THE SUSPENSION OF THE PUNITIVE PRETENSION \\ PRESCRIPTION IN THE COURTS OF ACCOUNTS UNDER \\ COVID-19 LAW
}

RICARDO SCHNEIDER RODRIGUES ${ }^{1}$

\begin{abstract}
RESUMO: Neste artigo é investigada a aplicação aos Tribunais de Contas da nova hipótese de suspensão do prazo prescricional da pretensão punitiva prevista na Lei da Covid-19 (art. 6º-C, parágrafo único, da Lei no 13.979/20 c/c MP nº 928/20). O método indutivo e a pesquisa documental foram utilizados para identificar a ratio decidendi dos julgados do STF sobre o tema da prescrição no âmbito dos TCs e, a partir daí, fazendo uso também de revisão bibliográfica, apurar se as razões invocadas pela Suprema Corte autorizam a aplicação da nova regra. Os achados da pesquisa demonstram que a suspensão da prescrição, embora configure restrição ao princípio da prescritibilidade, é medida razoável e proporcional, aplicável, por analogia, a todos os Tribunais de Contas. É também solução que se amolda ao princípio da segurança jurídica, impedindo a aplicação analógica das Leis $\mathrm{n}^{\mathrm{o}}$ 9.873/99 e n⿳0 13.979/20 de forma desuniforme, a partir de atos infralegais.
\end{abstract}

Palavras-chave: Tribunais de Contas; Direito Administrativo Sancionador; Sanção administrativa; Prescrição; Lei no 13.979/20.

\begin{abstract}
This article investigates the application to the Courts of Accounts of the new hypothesis of suspension of the punitive pretension of the punitive claim provided in the Covid-19 Law (art. 6-C, single paragraph, Law no 13.979/20 and Executive Act $\mathrm{n}^{\mathrm{o}}$ 928/20). The inductive method and the documentary research were used to identify the ratio decidendi of the judgements of the Supreme Court on the subject of prescription in the Courts of Accounts and, from there, also using bibliographic review, to determine if the reasons invoked by the Supreme Court authorize the application of the new rule. The research findings demonstrate that the suspension of the prescription, although it constitutes a restriction to the

\footnotetext{
${ }^{1}$ Doutor em Direito pela Pontifícia Universidade Católica do Rio Grande do Sul (PUC/RS). Professor do Centro Universitário Cesmac (Graduação e Mestrado). E-mail: prof.ricardo.schneider@hotmail.com.
} 
principle of prescribability, is a reasonable and proportional measure, applicable, by analogy, to all Courts of Accounts. It is also a solution that conforms to the principle of legal certainty, preventing the analogous application of Law $n^{0}$ 9.873/99 and Law $n^{-0} 13.979 / 20$ in an uneven manner, based on non-legal acts.

Keywords: Court of Accounts; Punitive Administrative Law; Administrative Penalty; Prescription; Law no 13.979/20.

\section{INTRODUÇÃO}

O Tribunal de Contas da União (TCU) e muitos dos Tribunais de Contas Estaduais e Municipais (TCs) não têm em suas leis orgânicas previsão acerca do prazo prescricional ou decadencial para o exercício de suas atividades finalísticas, tais como a emissão de pareceres prévios; julgamento de contas; registro de atos de admissão de pessoal, de aposentadorias, reformas e pensões; imputação de débito em casos de dano ao erário ou aplicação de penalidades. Essa lacuna normativa ainda gera muitos debates.

O consenso reside apenas em não se admitir a imprescritibilidade do poder sancionatório atribuído aos TCs no art. 71, inc. VIII, da Constituição da República (CR). A Constituição é expressa em apontar os casos em que há a imprescritibilidade de sanções, como nos crimes de racismo (art. $5^{\circ}$, inc. XLII, CR) e naqueles relacionados à ação de grupos armados, civis ou militares, contra a ordem constitucional e o Estado Democrático (art. 5o, inc. XLIV, CR). A Constituição prevê também a imprescritibilidade da pretensão de ressarcimento ao erário por dano decorrente da prática de ato doloso de improbidade administrativa (art. 37, § 5, CR).

O tema da prescrição vem sendo objeto de diversos julgados pelo Supremo Tribunal Federal (STF). Por ocasião do julgamento do Recurso Extraordinário (RE) no 852.475, com repercussão geral reconhecida, a Corte fixou a tese de que "são imprescritíveis as ações de ressarcimento ao erário fundadas na prática de ato doloso tipificado na Lei de Improbidade Administrativa". No RE no 669.069, definiu que "é prescritível a ação de reparação de danos à Fazenda Pública decorrente de ilícito civil".

Especificamente em relação aos Tribunais de Contas, no RE no 636.553 o Supremo mudou seu entendimento tradicional e passou a estabelecer que, "em atenção aos princípios da segurança jurídica e da confiança legítima, os Tribunais de Contas estão sujeitos ao prazo de 5 (cinco) anos para o julgamento da legalidade do ato de concessão inicial de aposentadoria, reforma ou pensão, a contar da chegada do processo à respectiva Corte de Contas". Mais recentemente, por ocasião do RE n⿳0 636.886, a Suprema Corte inovou outra vez, alterando sua jurisprudência para sufragar a tese de que “é prescritível a pretensão de ressarcimento ao erário 
fundada em decisão de Tribunal de Contas". No que se refere à pretensão punitiva, as duas turmas do STF já se manifestaram favoravelmente à aplicação da Lei $\mathrm{n}^{\mathrm{o}}$ 9.873, de 1999, aos TCs (BRASIL, 2019a; BRASIL, 2019c; BRASIL, 2017a).

A temática da prescrição é, portanto, relevante e precisa ser analisada em seus diferentes aspectos. Neste artigo o tema da investigação é a prescrição relacionada apenas ao poder sancionatório dos Tribunais de Contas (art. 71, inc. VIII, CR). Nos casos em que não há normas estabelecendo expressamente o prazo prescricional aplicável, as soluções encontradas pelos TCs variam. Enquanto o TCU adota as regras do Código Civil, ${ }^{2}$ outros Tribunais de Contas - e o próprio STF - adotam a Lei $n^{0}$ 9.873/99.3

Neste contexto, o estado de Emergência de Saúde Pública de Importância Internacional (ESPII), decorrente da Covid-19, também repercutiu sobre o tema. A Lei $\mathrm{n}^{\mathrm{o}}$ 13.979, de 2020, que dispõe sobre as medidas para o enfrentamento da pandemia, passou a prever, após a Medida Provisória (MP) no 928, de 2020, de forma expressa, a suspensão do transcurso dos prazos prescricionais para a aplicação de sanções administrativas previstos na Lei nº 9.873/99 (art. 6º-C, parágrafo único). Em relação aos prazos estabelecidos no Código Civil, tramita no Senado o Projeto de Lei no 1.179, de 2020, que, ao dispor sobre um regime jurídico emergencial e transitório das relações jurídicas de Direito Privado, propõe a suspensão dos respectivos prazos prescricionais e decadenciais.

O escopo deste trabalho consiste em analisar especificamente se, a partir da Lei da Covid-19 (nº 13.979/20 c/c MP no 928/20), a suspensão da prescrição nela prevista produz efeitos também no âmbito dos Tribunais de Contas que aplicam a Lei $\mathrm{n}^{\mathrm{o}}$ 9.873/99. Em outras palavras, este artigo propõe-se a investigar se a aplicação por analogia da referida norma implica a utilização, também, da nova regra que estabeleceu a suspensão do prazo prescricional durante o período de enfrentamento da pandemia.

Ademais, a regra da prescrição consiste numa garantia geral, decorrente do direito fundamental à segurança jurídica, a impedir que a Administração Pública exerça sua pretensão punitiva de forma ilimitada temporalmente. Daí a imprescindibilidade de se investigar, também, se essa restrição à garantia da prescrição da pretensão punitiva é válida.

Uma primeira hipótese possível consiste na inaplicabilidade da referida norma, ao menos aos Tribunais de Contas Estaduais e Municipais, por se tratar de lei

\footnotetext{
2 No Acórdão 679/2020, do Plenário, julgado em 25 de março de 2020, o TCU reiterou seu entendimento, nesse sentido: "A prescrição da pretensão punitiva do TCU subordina-se ao prazo geral de prescrição disposto na Lei 10.406/2002 (Código Civil) , dez anos, contado a partir da data da ocorrência da irregularidade e interrompido pelo ato que ordenar a citação, a audiência ou a oitiva da parte".

${ }^{3}$ É caso, por exemplo, dos Tribunais de Contas do Estado do Paraná (Prejulgado no 26), do Pará (Acórdão 58.818/2019) e de Alagoas (Súmula no 1). Cf. ainda EHRARDT JUNIOR; RODRIGUES, 2018.
} 
federal, competindo a cada Corte, no âmbito de sua autonomia, definir a suspensão dos prazos prescricionais por meio de atos individuais próprios, infralegais, de forma semelhante ao que vem ocorrendo em relação aos prazos processuais. Outra hipótese aventada sugere a incidência da nova regra a todos os Tribunais de Contas, suspendendo os prazos prescricionais para aplicação de sanções, por analogia, pelas mesmas razões que justificam a aplicação da Lei nº 9.873/99.

Fazendo uso do método indutivo, é realizada uma pesquisa documental, tendo por objeto Acórdãos da Suprema Corte que enfrentaram a questão da aplicação da Lei $\mathrm{n}^{\mathrm{0}}$ 9.873/99 pelos TCs, a fim de identificar seus argumentos centrais. Também serão objeto de análise algumas decisões monocráticas proferidas pelos Ministros não participantes das decisões colegiadas, de modo a permitir uma projeção quanto ao entendimento do Pleno do STF sobre o tema.

Passo seguinte, a ratio decidendi dos referidos julgados será examinada qualitativamente, em conjunto com outros substratos teóricos da doutrina especializada, por meio de revisão bibliográfica, com a finalidade de avaliar se tais razões também justificam a incidência da Lei no 13.979 /20 no âmbito dos Tribunais de Contas. Nesse ponto, as balizas teóricas que subsidiarão a investigação serão extraídas da concepção de que os Tribunais de Contas se submetem ao regime jurídico específico de Direito Administrativo, que influencia toda a sua atividade, além da teoria dos direitos fundamentais, na perspectiva da repercussão desses direitos sobre o exercício da atividade punitiva estatal.

\section{A PRESCRIÇÃO DA PRETENSÃO PUNITIVA DOS TRIBUNAIS DE CONTAS NA JURISPRUDÊNCIA DO SUPREMO TRIBUNAL FEDERAL}

Os Tribunais de Contas, por força do art. 71, inc. VIII, da Constituição, têm competência para aplicar aos responsáveis, em caso de ilegalidade de despesa ou irregularidade de contas, as sanções previstas em lei. Entre outras cominações possíveis, as respectivas leis orgânicas devem estabelecer a multa proporcional ao dano causado ao erário.

No âmbito do Tribunal de Contas da União, além das penalidades pecuniárias, tipificadas nos artigos 57 e 58 de sua Lei Orgânica (Lei no 8.443, de 1992 - LO/TCU), há a previsão das sanções de inidoneidade do licitante fraudador para participar, por até cinco anos, de licitação (art. 46), e de inabilitação do responsável, por um período de cinco a oito anos, para ocupar cargo em comissão ou função de confiança, no âmbito da Administração Pública, em caso de infração considerada grave (art. 60).

Com efeito, seguindo a lição de Cavalcanti (1999), observam-se nos processos de julgamento de contas três dimensões, a saber: a do julgamento da gestão propriamente dito, que busca a realização do princípio republicano; a de reparação do dano causado ao erário, de natureza indenizatória; e a de punibilidade do gestor faltoso, de natureza sancionatória, voltada direta e imediatamente ao gestor, único que poderá ser responsabilizado, nos termos do art. $5^{\circ}$, inciso XLV, da Constituição. 
Ferraz (2002) diferencia as espécies de penalidades ao alcance dos Tribunais de Contas. Para o autor, há aquelas decorrentes do poder de coerção e outras oriundas do poder de sanção. Exemplo de multas-coerção seriam as previstas para coagir indiretamente os responsáveis a cumprirem as obrigações previstas por lei e delimitadas em seus atos normativos, tais como o envio de relatórios e informações necessários à fiscalização, aproximando-se das medidas de polícia administrativa (art. 58, inc. VI, LO/TCU). As multas-sanção teriam viés estritamente sancionatório, incidentes, por exemplo, quando os responsáveis têm suas contas julgadas irregulares ou praticam ato de gestão ilegítimo ou antieconômico (art. 57 e 58, inc. I e II, LO/TCU).

Ainda acerca das sanções aplicáveis pelos Tribunais de Contas, importante o alerta de Osório (2011, p. 211-217) para as diferenças entre a legalidade penal e aquela atinente ao Direito Administrativo sancionador. Com efeito, o autor destaca que a legalidade no âmbito do Direito Administrativo possui certa flexibilidade. Regra geral, nesses casos os tipos são mais elásticos por força da própria dinâmica da Administração Pública. Não obstante, o autor ressalva que não se admite uma outorga total e completa pelo legislador, de modo a transferir por inteiro à autoridade a competência para tipificar a sanção administrativa, sob pena de tornar letra morta o princípio da legalidade.

Com efeito, Binenbojm (2017, p. 99-100) destaca que, embora o poder punitivo da Administração Pública tenha fundamento e limite no texto constitucional de forma semelhante às diretrizes estabelecidas no âmbito penal, há diferenças entre a legalidade estrita deste para a legalidade mais aberta daquele. Nesse sentido, Pelegrini (2014, p. 77-90) admite que o regulamento cumpra o papel de detalhar as condutas previstas de forma mais genérica na lei, conferindo maior segurança jurídica aos administrados, sem que isso signifique uma indevida delegação de competência legislativa ou a violação ao princípio da legalidade.

Vistos os aspectos gerais do poder sancionatório conferido aos Tribunais de Contas, necessário destacar que não existe no âmbito do controle externo, conforme asseverado inicialmente, uniformidade quanto ao prazo para a aplicação das penalidades previstas em suas leis orgânicas. Há Tribunais de Contas como os de Goiás, Sergipe, Minas Gerais, Rio Grande do Norte, Mato Grosso do Sul, Espírito Santo e Roraima que têm prazo prescricional previsto em lei específica. Dentre os TCs cujas leis orgânicas são omissas, há os que adotam o Código Civil e aqueles que aplicam a Lei no 9.873/99.

No âmbito do Supremo Tribunal Federal, a tese prevalecente nas duas turmas é favorável à aplicação da Lei no 9.873/99, que dispõe sobre o prazo prescricional da ação punitiva e da ação executória da Administração Pública Federal, direta e indireta, no exercício do poder de polícia. Não é objeto deste trabalho avaliar qual seria o entendimento mais adequado diante da lacuna - se aplicar as normas de Direito Privado ou de Direito Público. A proposta consiste apenas em analisar a questão a partir da jurisprudência consolidada no âmbito da Suprema Corte. 
Dessa forma, passa-se ao exame, neste ponto, das razões que justificaram a aplicação, pelo STF, das normas da Lei oำ 9.873/99, para extrair a ratio decidendi dos respectivos julgados. ${ }^{4}$

\subsection{A prescrição na visão da Primeira Turma do STF}

No acórdão proferido no Mandado de Segurança (MS) no 32.201/DF (BRASIL, 2017a), a Primeira Turma do STF decidiu, em 21 de março de 2017, pela aplicação da Lei no 9.873/99, por maioria, presentes três ministros: o Relator, Min. Roberto Barroso; a Min. Rosa Weber, que o acompanhou; e o Min. Marco Aurélio, vencido. A partir das razões expostas no voto vencedor, é possível elencar os argumentos que justificaram a aplicação da referida norma.

O Relator parte da seguinte premissa: a prescrição decorre do princípio geral da segurança das relações jurídicas, do qual se extrai a regra (geral) da prescritibilidade para todos os ramos do Direito. Tal proposição derivaria do disposto no art. 37, § 5o, da Constituição. Daí a necessidade de se delimitar um prazo para o exercício da pretensão punitiva pelo TCU, diante da lacuna normativa que se apresenta. O Relator aponta dois fundamentos autônomos que, isoladamente, têm o condão de sustentar a decisão proferida.

Defende, como primeiro argumento, a incidência direta da Lei no 9.873/99 ao caso, e não por analogia, por interpretar tal norma como sendo uma regra geral aplicável a qualquer ação punitiva da Administração Pública Federal, exceto nos casos em que houver norma específica tratando da matéria, como ocorre em relação à prescrição das penalidades aplicáveis aos servidores públicos federais e no âmbito tributário. Confere, portanto, uma interpretação ampliativa ao enunciado do art. $1^{\circ}$ da Lei $n^{0}$ 9.873/99 que, a rigor, restringe a sua incidência ao "exercício do poder de polícia". As sanções administrativas estariam sujeitas a um regime jurídico único, condicionado por diversos princípios constitucionais (legalidade, devido processo legal, contraditório e ampla defesa, segurança jurídica e irretroatividade, culpabilidade e pessoalidade da pena, individualização da sanção, razoabilidade e proporcionalidade).

O outro argumento invocado tem caráter alternativo. Caso não fosse acolhida a tese da aplicação direta da referida norma, a analogia também levaria ao mesmo resultado. Dada a autonomia científica do Direito Administrativo, não haveria razões para se recorrer às normas de Direito Civil em caso de lacuna. O prazo de cinco anos decorre de um amplo leque de normas de Direito Público coincidentes

\footnotetext{
${ }^{4} \mathrm{O}$ critério de pesquisa utilizado consistiu em decisões colegiadas do STF (Plenário e Turmas) que enfrentaram especificamente a questão do prazo prescricional para a aplicação de sanções por Tribunal de Contas. Foram identificados, segundo esses critérios, três acórdãos proferidos nos Mandados de Segurança no 36.067/DF, 35.512/DF e 32.201/DF (BRASIL, 2019a; BRASIL, 2019c; BRASIL, 2017a). Também foram identificadas algumas decisões monocráticas com o objetivo de avaliar o entendimento dos ministros não participantes do julgamento colegiado e, assim, traçar um perfil do provável entendimento do Plenário do STF quanto ao tema.
} 
quanto a este quantum de tempo. Pela especificidade da regulamentação em relação a todos os aspectos da prescrição, não apenas quanto ao prazo, defende a aplicação integral das regras da Lei n⿳0 9.873/99, em vez da criação de um regime híbrido.

Ao final, a Turma denegou a segurança por entender que, apesar de aplicada a Lei $n^{0}$ 9.873/99, a prescrição não teria ocorrido, por força da incidência das causas interruptivas do prazo, previstas no art. $2^{\circ}$ da referida Lei. O Min. Marco Aurélio, vencido na ocasião, embora tenha concordado com a aplicação da Lei ao caso, divergiu quanto à ocorrência da interrupção da prescrição, que, a seu ver, somente poderia ser considerada a partir da integração do responsável à relação processual administrativa. ${ }^{5}$

Pode-se afirmar, portanto, que os três ministros que participaram do referido julgado (Ricardo Lewandowski, Rosa Weber e Marco Aurélio) foram favoráveis à aplicação da Lei no 9.873/99 aos Tribunais de Contas.

Em decisões monocráticas é possível identificar o entendimento dos demais ministros integrantes do colegiado que não participaram do julgamento. O Min. Alexandre de Moraes, no MS nº 36.523/DF (BRASIL, 2019b), proferiu decisão monocrática reconhecendo a possibilidade de ocorrer a prescrição tanto da pretensão de ressarcimento ao erário quanto de penalidade imposta pelo TCU, conferindo ao art. 37, $\S 5^{\circ}$, da CR alcance mais restritivo. De igual forma decidiu no MS n 35.430/DF (BRASIL, 2017b). Não há, todavia, a indicação da norma que regulamentaria a prescrição no caso, se a Lei no 9.873/99, o Decreto $n^{0}$ 20.910/32 ou outra norma.

O Min. Luiz Fux, em decisão proferida no MS nº 36.127/DF (BRASIL, 2018), reconheceu, de forma expressa, a aplicação da Lei no 9.873/99 ao exercício da competência sancionatória pelo TCU, fazendo remissão ao julgado do MS $\mathrm{n}^{\mathrm{o}}$ 32.201/DF, da Primeira Turma.

Em conclusão parcial, pode-se afirmar que, no âmbito da Primeira Turma do STF, todos os ministros entendem que a função sancionatória do TCU está sujeita a prazo prescricional, havendo quatro manifestações expressas no sentido da aplicação da Lei no 9.873/99. Os argumentos que sustentam a incidência da referida norma foram explicitados apenas no Acórdão do MS nº 32.201/DF.

\section{A prescrição na visão da Segunda Turma do STF}

No acórdão do MS no 35.512/DF (BRASIL, 2019c), a Segunda Turma do STF também decidiu, em 4 de junho de 2019, pela aplicação da Lei no 9.873/99 no âmbito do TCU, por unanimidade, presentes todos os integrantes do colegiado: Min. Ricardo Lewandowski, Relator, Min. Celso de Mello, Min. Gilmar Mendes, Min. Cármen Lúcia e Min. Edson Fachin.

\footnotetext{
${ }^{5}$ Em sede de Decisão Monocrática proferida na Medida Cautelar no MS no 36.477/DF, em 21 de junho de 2019, o Min. Marco Aurélio reiterou seu posicionamento, indo além para considerar a aplicação do prazo prescricional de cinco anos não apenas para a pretensão punitiva, mas, também, para a hipótese de ressarcimento ao erário.
} 
Em seu voto, o Relator analisou também a questão do ressarcimento ao erário, para defender a tese de que apenas os valores perseguidos na esfera judicial e que não consubstanciassem mero ilícito civil estariam a salvo da prescrição. A busca pelo ressarcimento ao erário pela via da Tomada de Contas Especial, no âmbito do TCU, sofreria os efeitos da prescrição. Embora o voto abranja essa questão, a ressalva do Min. Edson Fachin, em seu voto-vista, permite inferir que na ocasião os julgadores estavam considerando a controvérsia relativa à prescrição como limitada apenas à aplicação da sanção.

Sem embargo, é possível vislumbrar uma tendência no âmbito da Suprema Corte em relativizar a antiga noção ampla da imprescritibilidade do ressarcimento ao erário. ${ }^{6}$ Isso se verifica, num primeiro momento, no julgamento do RE $n^{0} 852.475$, quando a Corte restringiu a imprescritibilidade apenas às ações de ressarcimento ao erário fundadas na prática de ato doloso tipificado na Lei de Improbidade Administrativa. Posteriormente, no RE no 669.069, o STF assentou a prescritibilidade da ação de reparação de danos à Fazenda Pública decorrente de mero ilícito civil. Em seguida, no RE no 636.886, a jurisprudência foi alterada para consolidar a possibilidade de prescrição da pretensão de ressarcimento ao erário fundada em decisão de Tribunal de Contas. ${ }^{7}$

Retomando a análise do MS no $35.512 / \mathrm{DF}$, em seu voto o Relator parte da premissa de que o art. 37, § 5을 da Constituição, à luz dos julgados e pareceres mencionados no voto, ressalvaria da prescrição apenas o ressarcimento dos valores perseguidos judicialmente e decorrentes de ilegalidade de despesa ou irregularidade de contas. Não são apresentadas, de forma específica, as razões para a escolha da Lei $\mathrm{n}^{\mathbf{0}}$ 9.873/99 para regulamentar a função sancionatória dos Tribunais de Contas, fazendo remissão ao julgado do MS nํㅜ 32.201/DF, da Primeira Turma do STF.

O último acórdão identificado foi proferido no MS no 36.067/DF (BRASIL, 2019a), pela Segunda Turma do STF, que também decidiu, em 18 de outubro de 2019, no sentido da aplicação da Lei oํ 9.873/99 ao TCU. Para o Relator, nos termos do julgado anteriormente mencionado (MS no 35.512/DF), a prescrição alcançaria a pretensão punitiva e o ressarcimento ao erário, ressalvando apenas o ressarcimento de valores pela via judicial. No caso, não fora reconhecida a prescrição em razão da ocorrência das interrupções do prazo, previstas na referida Lei. Quanto às razões

\footnotetext{
6 No âmbito da doutrina, a mudança na interpretação do $\S 5^{\mathbf{0}}$ do art. 37 da Constituição, antes compreendido como uma regra que assegurava a imprescritibilidade do ressarcimento ao erário de forma ampla, é atribuída a Emerson Gabardo (2019), que levou Celso Antônio Bandeira de Mello a rever seu entendimento (2015, p. 1.092-1.093).

7 Nesse caso, a prescrição ocorreu em sede de execução fiscal, após a constituição do título executivo extrajudicial pelo TCU. A extinção do feito fundamentou-se no art. 40, § $4^{\circ}$, da Lei no $6.830 / 80$, por ter ficado o processo suspenso, sem terem sido encontrados bens do devedor, pelo prazo da prescrição. O caso concreto não versava, portanto, sobre a ocorrência de prescrição anteriormente ao Acórdão condenatório do TCU.
} 
para a escolha da Lei no 9.873/99, novamente se fez remissão ao julgado da Primeira Turma. A decisão também foi unânime, presentes, além do Relator, Min. Ricardo Lewandowski, a Min. Cármen Lúcia, o Min. Celso de Mello, o Min. Gilmar Mendes e o Min. Edson Fachin.

É possível concluir, portanto, a partir dos referidos julgados, que a maioria dos Ministros do STF (oito) já se manifestou, nas respectivas Turmas, a favor da aplicação da Lei no 9.873/99 para regulamentar o exercício da pretensão punitiva pelo TCU, diante da lacuna normativa constatada. Considerando as decisões monocráticas, são nove ministros expressamente favoráveis à aplicação da referida Lei - as decisões do Min. Alexandre de Moraes revelam sua concordância quanto à prescritibilidade das sanções, mas não indicam de forma clara qual norma seria aplicável. Não foram identificadas decisões do Min. Dias Toffoli sobre o tema. A ratio decidendi pertinente à escolha da Lei no 9.873/99 está evidenciada, portanto, no julgado da Primeira Turma (MS no 32.201/DF), reiterado em dois julgados da Segunda Turma.

Cumpre agora analisar se as razões que levaram o Supremo Tribunal Federal a concluir pela aplicação da Lei no 9.873/99, indicadas no MS nº 32.201/DF, justificam, também, a aplicação da nova regra estabelecida na Lei da Covid-19.

\section{A INCIDÊNCIA DA LEI DA COVID-19 NO ÂMBITO DOS TRIBUNAIS DE CONTAS}

A investigação realizada permite afirmar a existência de um consenso no Supremo Tribunal Federal quanto à ocorrência do fenômeno da prescrição da pretensão punitiva no âmbito dos TCs, independentemente da existência de lei específica prevendo o fenômeno. O STF reconhece a prescritibilidade das sanções como uma regra geral a ser afastada somente em casos excepcionais, quando o próprio texto constitucional a ressalva.

Para a Suprema Corte, tal regra (geral) da prescritibilidade produz efeitos em todos os ramos do Direito e, especificamente em relação ao Direito Administrativo, deriva do disposto no art. $37, \S 5^{\circ}$, da Constituição, ao prever que a lei disporá sobre os prazos prescricionais para ilícitos praticados por qualquer agente.

Além disso, extrai-se da jurisprudência do STF a ideia de um regime jurídico equivalente a um verdadeiro "estatuto constitucional do poder punitivo estatal", que regeria o Direito Administrativo sancionador. Tal regime seria integrado por diversos princípios, como o da legalidade (art. 5º inc. II, e 37, caput, CR); do devido

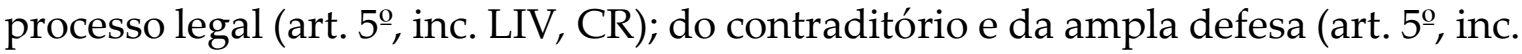
LV, CR); da segurança jurídica e da irretroatividade (art. 5ํㅜ caput, inc. XXXIX e XL, CR); da culpabilidade e da pessoalidade da pena (art. 5ㅇ, inc. XLV, CR); da individualização da sanção (art. 5o , inc. XLVI, CR); da razoabilidade e da proporcionalidade (arts. $1^{\mathrm{o}}$ e $5^{\mathrm{o}}$, inc. LIV, CR).

Quanto à aplicação da Lei n⿳0 9.873/99, a Suprema Corte apresenta dois argumentos autônomos. Um correspondente à aplicação direta da referida lei, pois se trataria de uma norma geral regulamentadora da ação punitiva da 
Administração Pública Federal, no exercício do poder administrativo sancionador. O segundo, no sentido da aplicação da Lei n $9.873 / 99$ por analogia, por se tratar de matéria inerente ao regime jurídico-administrativo - não atraindo, portanto, regras de direito privado para a colmatação de lacunas. Além disso, entre as normas de Direito Público, a referida lei seria a que melhor se adapta às peculiaridades da prescrição da pretensão punitiva no âmbito do TCU, afastando a possibilidade de criação de uma nova norma a partir de enunciados de diferentes leis (híbrida).

Nesse contexto, cumpre avaliar, inicialmente, se a norma do art. $6^{\circ}-\mathrm{C}$, parágrafo único, da Lei no 13.979/20, inserida pela MP no 928/20, que prevê a suspensão do transcurso dos prazos prescricionais para a aplicação das sanções administrativas previstas na Lei $\mathrm{n}^{\mathbf{0}}$ 9.873/99, enquanto pendente o estado de calamidade, é compatível com o referido arcabouço jurídico constitucional. Em seguida, serão analisados os dois argumentos veiculados pelo STF no MS no 32.201/DF, em relação ao TCU e aos demais Tribunais de Contas, para avaliar se o novo dispositivo legal também se aplica a todos os TCs brasileiros.

\subsection{A suspensão do prazo prescricional pela Lei da Covid-19 à luz do "estatuto constitucional do poder punitivo estatal"}

Pode-se atestar, à luz da jurisprudência do STF, a existência de um regime jurídico constitucional voltado à proteção de todos que possam ser submetidos a uma sanção administrativa. Um dos reflexos desse regime consiste na garantia fundamental que impede uma sujeição temporalmente ilimitada ao poder punitivo estatal. Em outras palavras, há um dever público de o Estado limitar o seu próprio poder punitivo no tempo, pela adoção de prazos prescricionais ou decadenciais razoáveis.

O texto constitucional excepciona por completo tal garantia apenas em hipóteses expressas, nas quais outros valores justificaram a sua supressão: crimes de racismo (art. 5, inc. XLII, CR), crimes relacionados à ação de grupos armados, civis ou militares, contra a ordem constitucional e o Estado Democrático (art. 5\%, inc. XLIV, CR), e no caso de ressarcimento ao erário por dano decorrente da prática de ato doloso de improbidade administrativa (art. $37, \S 5^{\circ}, \mathrm{CR}$ ).

A doutrina segue a mesma trilha. Binenbojm (2017, p. 99-103) assevera que o regime jurídico aplicável ao poder punitivo estatal encontra fundamento e limite, de forma aproximada, na sistemática adotada pela Constituição para o Direito Penal. Com razão, aduz que o poder punitivo é um dos campos do Direito Administrativo mais influenciados pela Constituição e defende a repercussão nele de diversas garantias associadas ao Estado Democrático de Direito, insculpidas no art. $5^{\mathrm{o}}$ da Constituição, tais como os princípios da segurança jurídica, do devido processo legal, da razoabilidade e da proporcionalidade.

Também assim destaca Osório (2011, p. 137), ao demonstrar que, embora não se submetam ao mesmo regime jurídico nem se valham das mesmas técnicas sempre, o Direito Penal e o Direito Administrativo sancionador "acabam adentrando nos 
núcleos estruturantes dos direitos fundamentais dos acusados em geral, na perspectiva de submissão às cláusulas do devido processo legal e do Estado de Direito".

Por tal raciocínio, toda norma que limite a regra da prescritibilidade deverá ser examinada com cautela, pois, ao fim e ao cabo, limita uma série de direitos e garantias fundamentais que estão materializados nesse regime jurídico especial que corporifica o Direito Administrativo sancionador.

Com efeito, "ao sancionar os particulares, a Administração lhes impõe gravame que afeta de forma severa a sua esfera de direitos fundamentais". Daí a necessidade de submeter tal atividade ao sistema de princípios e regras protetivos dos administrados, como abrigo contra eventuais abusos no exercício desse poder (BINEMBOJM, 2014, p. 468-469).

Estabelecer prazos prescricionais manifestamente extensos ou hipóteses de interrupção ou suspensão desarrazoadas vulneraria o núcleo essencial dessas garantias e, por conseguinte, dos princípios da segurança jurídica, do devido processo legal, da razoabilidade e da proporcionalidade.

Esse entendimento é compartilhado por Osório (2011), que defende, no âmbito do Direito Administrativo sancionador, a existência de um "princípio da prescrição", decorrente do princípio da segurança jurídica. Para o autor, tais princípios impõem que "toda e qualquer pretensão punitiva deva estar submetida a limites temporais para seu exercício, sob pena de violação à segurança jurídica, inerente ao Estado de Direito" (2011, p. 438-439).

De igual modo, Pelegrini (2014, p. 178-181) destaca que o conteúdo do princípio da segurança jurídica vai além daquele previsto no inciso XIII do parágrafo único do art. $2^{\circ}$ da Lei $\mathrm{n}^{0}$ 9.874/99, para abarcar a estabilidade das relações jurídicas, que tem como importante arrimo o instituto da prescrição, ao lado da decadência e da preclusão. Tais institutos, afirma, são instrumentos voltados à estabilidade das relações jurídicas, integrante do princípio da segurança jurídica, que é fundamento do Estado de Direito (2017, p. 191). A autora traz a lume, ainda, o preceito constitucional que assegura, inclusive no âmbito administrativo, o direito à razoável duração do processo e dos meios que garantam a celeridade de sua tramitação (art. 5으, inc. LXXVIII, CR), como uma das garantias estabelecidas em prol da estabilização das relações jurídicas e da segurança jurídica, todos aplicáveis à função controladora exercida pelos Tribunais de Contas (2017, p. 191-193).

Analisados os aspectos gerais desse regime jurídico específico do denominado Direito Administrativo sancionador ou punitivo, passa-se ao exame da nova regra atinente à prescrição, inserida pela MP nº 928/20 na Lei da Covid-19.

A primeira constatação a merecer registro corresponde ao fato de que o art. $6^{0}$ C, parágrafo único, da Lei no 13.979/20 não veicula hipótese de interrupção, mas de suspensão do prazo prescricional. Assim, superado o fato ensejador da suspensão - no caso, a pandemia -, o prazo torna a fluir, não havendo o reinício da contagem (CARVALHO FILHO, 2012, p. 69). 
Ademais, a Lei estabelece, no caput do art. $6^{-}-\mathrm{C}$, que os prazos processuais em desfavor dos acusados e entes privados, em processos administrativos, também não fluirão nesse período. Dessa forma, há uma via de mão dupla, pois ao tempo que a Administração Pública, limitada em suas atividades em razão da pandemia, tem os prazos para exercer seu poder punitivo suspensos, os particulares também têm os prazos contra si paralisados.

Numa primeira análise, a suspensão dos prazos prescricionais para a aplicação de sanções administrativas no período da pandemia não se apresenta como violadora dos princípios norteadores do Direito Administrativo sancionador, em especial da regra da prescritibilidade das sanções. É natural que num contexto de evidente calamidade pública, as atividades desempenhadas pela Administração Pública sofram limitações, repercutindo em todas as esferas, inclusive no exercício da sua função sancionatória. Restando inviabilizada ou prejudicada a atuação estatal por fatores externos e alheios à própria Administração Pública, é razoável que os prazos extintivos atrelados a essa atuação sejam suspensos até a normalização de suas atividades.

O regime jurídico administrativo é marcado por prerrogativas e sujeições do poder público (DI PIETRO, 2019, p. 86). ${ }^{8}$ Os tradicionais princípios da supremacia do interesse público sobre o privado e da indisponibilidade, pela Administração, dos interesses públicos, ainda que mereçam releitura, continuam a traduzir as especificidades desse regime. ${ }^{9}$ Em relação propriamente à função sancionatória, é possível estabelecer sua vinculação com os dois princípios.

A possibilidade de aplicar sanções sem depender do Poder Judiciário, constituindo relações jurídicas que vinculam terceiros unilateralmente, é reflexo do princípio da supremacia do interesse público sobre o privado. Com Mello se percebe que a Administração ocupa uma posição privilegiada a fim de zelar pelo interesse público, encarnando certas prerrogativas instrumentais que a ordem jurídica lhe assegura para viabilizar o cumprimento do seu papel (2015, p. 71-72). É indispensável para a concretização do interesse público que a Administração possua meios para coagir os particulares - e, eventualmente, como ocorre nos Tribunais de Contas, aqueles que exercem funções públicas - a cumprirem suas obrigações legais.

Por outra via, não está ao alcance do arbítrio de quem exerce tal função sancionatória exercê-la quando convém. Ainda com Mello, qualificando-se os

\footnotetext{
${ }^{8}$ Nohara traduz essa "bipolaridade" em autoridade da Administração versus a liberdade do indivíduo (NOHARA, 2019).

9 "Todo o sistema de Direito Administrativo, a nosso ver, se constrói sobre os mencionados princípios da supremacia do interesse público sobre o particular e indisponibilidade do interesse público pela Administração" (MELLO, 2015, p. 57). Sobre uma proposta de releitura do princípio da supremacia do interesse público, cf. BINENBOJM, 2005; SUNDFELD, 2012, p. 47-48. Em resposta às críticas voltadas à noção de supremacia do interesse público, cf. CARVALHO FILHO, 2019, p. 112-113.
} 
interesses públicos como próprios da coletividade, não se admite que estejam à livre disposição de quem exerça o múnus público, visto que inapropriáveis (2015, p. 76-77). Aqui a indisponibilidade do interesse público impõe a atuação estatal no sentido de fazer cumprir a lei, aplicando as penalidades cabíveis, se for o caso.

Numa análise à luz da proporcionalidade, a norma que suspende os prazos prescricionais afigura-se adequada, pois fomenta o princípio da indisponibilidade do interesse público, ao permitir que a Administração Pública exerça essa função oportunamente, quando os meios necessários para alcançar tal desiderato forem restabelecidos. É, também, necessária, pois não se vislumbram outros meios menos gravosos à garantia da prescritibilidade das sanções administrativas e que alcancem o mesmo resultado decorrente da suspensão do prazo prescricional, no atual cenário de enfrentamento à pandemia, onde os esforços estão concentrados na preservação da saúde pública.

Por fim, num juízo de proporcionalidade em sentido estrito, considera-se que os ganhos para o interesse público compensam o prejuízo individual com a suspensão do prazo prescricional, em especial porque a norma também previu medida semelhante em favor dos particulares, no caput do seu art. $6^{\circ}-\mathrm{C}$. Foram suspensos não apenas os prazos prescricionais - favorecendo a Administração Pública, mas também os prazos processuais desfavoráveis aos acusados e entes privados em processos administrativos. ${ }^{10}$

Nesta primeira etapa, pode-se concluir que a norma é razoável e proporcional, não violando os princípios norteadores do Direito Administrativo sancionador, em especial a garantia de prescritibilidade das sanções.

Passa-se agora ao exame da questão relacionada à aplicação aos TCs da nova norma suspensiva dos prazos prescricionais, à luz da jurisprudência do STF.

\subsection{A tese da aplicação direta da Lei no 9.873/99 ao TCU e a Lei da Covid-19}

Não há maiores dúvidas que, adotada a tese da aplicação direta da Lei $\mathrm{n}^{\mathrm{o}}$ 9.873/99 - e não por analogia -, ao argumento de que representaria um verdadeiro estatuto geral da prescrição da ação punitiva para toda a Administração Pública Federal, inclusive para o TCU, a criação, por lei federal, de uma nova hipótese de suspensão do prazo prescricional aplicar-se-ia, sem maiores dificuldades, ao referido Tribunal.

A única ressalva que poderia ser oposta concerne à eventual violação, por essa norma, das garantias fundamentais estatuídas no denominado "estatuto constitucional do poder punitivo estatal". Como visto anteriormente, não há razões que justifiquem considerar a ocorrência de qualquer violação.

Por essa linha de argumentação, a causa suspensiva prevista na Lei no 13.979/20 seria aplicável, também, ao TCU, de forma direta, independentemente de analogia.

10 Sobre a utilização da regra da proporcionalidade e seus elementos (sub-regras) adequação, necessidade e proporcionalidade em sentido estrito, cf. SILVA, 2002. 
3.3 A tese da aplicação direta da Lei no 9.873/99 aos Tribunais de Contas dos Estados e de Municípios e a Lei da Covid-19

Além do TCU, a Constituição previu a existência de Tribunais de Contas Estaduais e manteve a existência dos Tribunais de Contas dos Municípios do Rio de Janeiro e de São Paulo. A questão que surge, portanto, é saber se a "Lei geral da prescrição da ação punitiva da Administração Pública Federal" teria aplicação direta aos Tribunais de Contas integrantes dos entes subnacionais - isto é, sem analogia -, conforme a primeira das teses sustentadas pelo STF.

A resposta é negativa. Conforme asseverado anteriormente, diversos Tribunais de Contas já regulamentaram o tema da prescrição - e até da decadência - nos respectivos âmbitos de atuação. Não se trata de matéria atinente à competência da União, mas reservada a cada Tribunal de Contas local, a quem o STF assegurou, em diversos julgados, a reserva de iniciativa de lei para dispor sobre sua competência e funcionamento. ${ }^{11}$

Desta forma, à luz da Constituição, não há margem para conferir à Lei $\mathrm{n}^{\mathrm{o}}$ 9.873/99 um caráter de lei nacional, regulamentadora da prescrição da ação punitiva da Administração Pública em todos os níveis: federal, estadual e municipal. A sua aplicação, por conseguinte, somente poderia ocorrer por analogia, diante da ausência de norma local específica sobre o tema.

Por tais razões, a aplicação da Lei no 13.979/20, de forma direta, não seria possível em relação aos Tribunais de Contas Estaduais e de Municípios.

\subsection{A tese da aplicação analógica da Lei no $9.873 / 99$ a todos os Tribunais de Contas e a Lei da Covid- 19}

No julgado do MS no 32.201/DF, o STF apresentou argumentação alternativa. Ainda que superada a tese da aplicação direta da Lei no 9.873/99, restou consagrado o entendimento de que a referida norma poderia ser aplicada por analogia ao TCU. Assentadas as mesmas razões que justificam a aplicação da referida norma ao TCU, seria possível defender, também, a aplicação da Lei no $13.979 / 20$, por analogia, a todos os TCs? Não competiria ao próprio TCU e aos demais TCs delimitar a suspensão desse prazo prescricional individualmente, por atos infralegais próprios?

11 “Na linha da jurisprudência pacífica e reiterada do Supremo Tribunal Federal, estende-se aos Tribunais de Contas, como corolário das prerrogativas de independência e autonomia asseguradas às Cortes de Contas pela Lei Maior do país (arts. 73 e 75), a reserva de iniciativa para deflagrar o processo legislativo que tenha por objeto alterar a sua organização ou o seu funcionamento (art. 96, II, da Constituição da República). A promulgação de emenda a constituição estadual não constitui meio apto para contornar a cláusula de iniciativa reservada, que se impõe seja diante do texto original seja do resultante de emenda. A inobservância da regra constitucional de iniciativa legislativa reservada acarreta a inconstitucionalidade formal de norma resultante" (BRASIL, 2019d). 
A aplicação analógica impõe, tanto quanto possível, a submissão ao regime jurídico da norma de referência, sob pena de se criar um regime híbrido, a invadir o espaço de competência reservado ao legislador. Aliás, não foi outro o entendimento veiculado pelo STF ao tratar da temática, quando o Relator assentou não ser adequada a criação de um regime híbrido, "mas a aplicação integral da regulação estabelecida pela Lei no 9.873/1999" (BRASIL, 2017a).

Desta forma, a nova causa de suspensão da prescrição, estabelecida pela Lei ${ }^{\circ}$ 13.979/20, passou a integrar o regime jurídico da Lei nº 9.873/99, não sendo possível afastar a sua aplicação no âmbito do TCU e dos demais Tribunais de Contas que utilizam a referida norma por analogia.

Sem embargo, conforme asseverado anteriormente, a previsão do caput do art. 6--C da Lei da Covid-19 complementa o disposto em seu parágrafo único. Dessa forma, ainda que se trate de matéria de competência reservada aos TCs, nos processos administrativos em que houver a suspensão da pretensão punitiva também deverá ser reconhecida a suspensão dos prazos em desfavor dos acusados e dos entes privados. Essa medida é essencial para preservar a constitucionalidade do dispositivo, pelas razões anteriormente apresentadas.

Permitir que cada Tribunal discipline a suspensão da pretensão punitiva quando não há norma expressa regulando a matéria redundaria, ao final, em permissão para que cada TC passasse a instituir um regime jurídico infralegal próprio em matéria prescricional, em vez de aplicar uma norma legal preexistente, por analogia, vulnerando o princípio da legalidade. Isso traria grande aumento de insegurança jurídica, pois, embora aplicasse a Lei no 9.873/99 por analogia, cada Corte de Contas passaria a disciplinar de forma diferente os seus marcos suspensivos e interruptivos.

Por outra via, a regra instituidora da suspensão do prazo prescricional da pretensão punitiva é uma regra mais gravosa para o indivíduo acusado da prática de algum ilícito administrativo, porquanto confere mais tempo para o poder público aplicar-lhe a penalidade correspondente.

Enquanto a aplicação, por analogia, da Lei oํ 9.873/99, num cenário de lacuna normativa, vai ao encontro da vedação de penas imprescritíveis, a previsão de hipótese suspensiva mitiga esse direito individual. Daí a imprescindibilidade de lei para disciplinar a questão em tais casos. Na ausência de lei local, deve-se aplicar outra norma por analogia. A vulgarização da previsão de hipóteses suspensivas da prescrição, a partir de atos normativos infralegais ao alcance de cada Tribunal, poderia abrir precedente perigoso no sentido de postergar o desfecho de prazos extintivos em outros casos que não exijam providências tão abrangentes como o da atual pandemia, em prejuízo dos acusados. A situação é, portanto, diversa da mera suspensão dos prazos processuais, requerendo um tratamento uniforme e por lei. ${ }^{12}$

12 Por meio da Portaria-TCU nº 61, de 19 de março de 2020, o Presidente do TCU suspendeu por 30 (trinta) dias corridos os prazos processuais no âmbito do TCU. Em seguida, por meio da Portaria 
Se a previsão de prazo prescricional para a aplicação de penalidades é uma decorrência da Constituição, que prevê as hipóteses de imprescritibilidade como exceções, toda medida que redunde na ampliação desse prazo deve ser vista com maior cautela e rigor.

Dessa forma, diante da ausência de lei local específica disciplinando a matéria, os TCs que aplicam a Lei $n^{-}$9.873/99 por analogia devem, pelas mesmas razões, submeter-se à regra da Lei no 13.979/20 c/c a MP nº 928/2020, que estabeleceu a suspensão do prazo prescricional para a aplicação das sanções lá previstas, sendo vedado disciplinar tal questão de forma diversa por ato infralegal. Em outras palavras, o recurso à analogia impõe a submissão ao regime jurídico do respectivo instituto por inteiro, assegurando a necessária segurança jurídica aos acusados em geral. É vedado ao aplicador do direito instituir um novo regime a partir de um juízo eminentemente subjetivo, pois além de ferir o princípio da legalidade e extrapolar suas competências institucionais (restritas à inciativa de projeto de lei), criaria, por ato infralegal, uma restrição a direito individual.

\section{CONCLUSÃO}

A proposta deste trabalho consistiu em investigar se a suspensão dos prazos prescricionais para aplicação de sanção, prevista no parágrafo único do art. $6^{-}-\mathrm{C}$ da Lei da Covid-19 (no 13.979/20 c/c MP no 928/20), seria aplicável aos Tribunais de Contas ou, caso contrário, se cada Corte poderia disciplinar a questão individualmente, por meio de ato infralegal. A metodologia utilizada para o enfrentamento da questão correspondeu, em linhas gerais, à análise dos julgados da Suprema Corte e à aplicação da ratio decidendi deles à nova hipótese normativa.

Após a investigação, foi possível constatar o reconhecimento, no âmbito do STF, da existência de uma regra geral de prescritibilidade das sanções aplicáveis pela Administração Pública, como decorrência do estatuto constitucional de direitos e garantias fundamentais regentes do denominado Direito Administrativo sancionador.

Em caso de inexistência de norma a disciplinar a prescrição, no âmbito do poder punitivo da Administração Pública, o Supremo defende duas teses alternativas: a da aplicação direta da Lei $\mathrm{n}^{\mathbf{0}}$ 9.873/99, por ser considerada uma regra geral regulamentadora do poder punitivo da Administração Pública Federal; e a da aplicação analógica, por representar, a referida lei, entre as normas de Direito Público, aquela que mais se amolda à situação fática do exercício do poder sancionatório pelos TCs.

Nesse contexto, a suspensão do prazo prescricional previsto na Lei no 9.873/99 pela Lei n⿳0 13.979/20, após a MP no 928/20, é considerada como medida razoável e proporcional. A sua aplicação analógica aos Tribunais de Contas é possível, pois as mesmas razões que justificam o uso da Lei $n^{0}$ 9.873/99 se fazem presentes em

no 71 , de 16 de abril de 2020, a suspensão dos prazos processuais foi prorrogada até o dia 20 de maio de 2020. 
relação ao novo regramento. A aplicação direta da referida norma, todavia, somente seria possível em relação ao TCU, e não pelos Tribunais de Contas Estaduais e Municipais, por se tratar de matéria submetida à reserva de iniciativa desses entes.

A aplicação da nova norma aos TCs é a solução mais condizente com o princípio da segurança jurídica, que integra o regime jurídico do Direito Administrativo sancionador, a afastar a possibilidade de que a suspensão dos prazos prescricionais - verdadeira restrição ao princípio da prescritibilidade - ocorra por meio de atos infralegais diversos e desuniformes. Ademais, é medida que evitaria a criação de normas híbridas por cada Tribunal de Contas, em sentido contrário ao da jurisprudência do STF e em violação ao princípio da segurança jurídica.

Por último, a fim de preservar a compatibilidade da nova hipótese de suspensão com o estatuto constitucional do Direito Administrativo sancionador, nos processos em que a suspensão da pretensão punitiva for reconhecida em favor do poder público, também deverão ser considerados suspensos os prazos processuais que corriam em desfavor dos acusados e dos entes privados, nos termos do caput do art. 6-C da Lei da Covid-19.

\section{REFERÊNCIAS}

BINENBOJM, Gustavo. Poder de Polícia, ordenação e regulação: transformações político-jurídicas, econômicas e institucionais do Direito Administrativo Ordenador. 2. ed. Belo Horizonte: Fórum, 2017.

BINENBOJM, Gustavo. O Direito Administrativo Sancionador e o Estatuto Constitucional do Poder Punitivo Estatal: possibilidades, limites e aspectos controvertidos da regulação do setor de revenda de combustíveis. Revista de Direito da Procuradoria Geral, Edição Especial, p. 468-491, 2014.

BINENBOJM, Gustavo. Da supremacia do interesse público ao dever de proporcionalidade: um novo paradigma para o Direito Administrativo. Quaestio Iuris, v. 1, n. 2, p. 27-63, 2005.

BRASIL. Supremo Tribunal Federal (2. Turma). Ag. Reg. nos Emb. Decl. em Mandado de Segurança 36.067/DF. Relator: Min. Ricardo Lewandowski, 18 de outubro de 2019. Disponível em:

http://portal.stf.jus.br/processos/detalhe.asp?incidente=5576896. Acesso em: 21 abr. 2020.

BRASIL. Supremo Tribunal Federal. Decisão monocrática em Medida Cautelar no Mandado de Segurança 36.523/DF. Relator: Min. Alexandre de Moraes, 17 de junho de 2019. Disponível em: 
http://portal.stf.jus.br/processos/detalhe.asp?incidente=5716397. Acesso em: 22 abr. 2020.

BRASIL. Supremo Tribunal Federal (2. Turma). Ag. Reg. em Mandado de Segurança 35.512/DF. Relator: Min. Ricardo Lewandowski, 4 de junho de 2019. Disponível em: http://portal.stf.jus.br/processos/detalhe.asp?incidente $=5345584$. Acesso em: 21 abr. 2020.

BRASIL. Supremo Tribunal Federal (2. Turma). Ação Direta de Inconstitucionalidade 5.323/RN. Relator: Min. Rosa Weber, 11 de abril de 2019. Disponível em: http://portal.stf.jus.br/processos/detalhe.asp?incidente=4780124. Acesso em: 24 abr. 2020.

BRASIL. Supremo Tribunal Federal. Decisão monocrática em Medida Cautelar no Mandado de Segurança 36.127/DF. Relator: Min. Luiz Fux, 28 de novembro de 2018. Disponível em:

http://portal.stf.jus.br/processos/detalhe.asp?incidente=5596224. Acesso em: 22 abr. 2020.

BRASIL. Supremo Tribunal Federal (1. Turma). Mandado de Segurança 32.201/DF. Relator: Min. Roberto Barroso, 21 de março de 2017. Disponível em: http://portal.stf.jus.br/processos/detalhe.asp?incidente=4435867. Acesso em: 21 abr. 2020.

BRASIL. Supremo Tribunal Federal. Decisão monocrática em Medida Cautelar no Mandado de Segurança 35.430/DF. Relator: Min. Alexandre de Moraes, 19 de dezembro de 2017. Disponível em:

http://portal.stf.jus.br/processos/detalhe.asp?incidente=5330185. Acesso em: 22 abr. 2020.

CARVAlHO FILHO, José dos Santos. Manual de Direito Administrativo. 33. ed. São Paulo: Atlas, 2019.

CARVALHO FILHO, José dos Santos. Improbidade Administrativa: prescrição e outros prazos extintivos. São Paulo: Atlas, 2012.

CAVALCANTI, Augusto Sherman. O processo de contas no TCU: o caso do gestor falecido. Revista do Tribunal de Contas da União, v. 30, n. 81, p. 17-27, jul./set. 1999.

DI PIETRO, Maria Sylvia Zanella. Direito Administrativo. 32. ed. Rio de Janeiro: Forense, 2019. 
EHRARDT JUNIOR, Marcos; RODRIGUES, Ricardo Schneider. Seqüiência, Florianópolis, n. 79, p. 89-118, ago. 2018. Disponível em:

https://periodicos.ufsc.br/index.php/sequencia/article/view/2177-

7055.2018v39n79p89/37634. Acesso em: 20 abr. 2020.

FERRAZ, Luciano. Poder de coerção e poder de sanção dos Tribunais de Contas: competência normativa e devido processo legal. Revista Diálogo Jurídico, n. 13, abr./maio 2002.

GABARDO, Emerson; SAIKALI, Lucas Bossoni. Crítica à decisão do STF sobre a imprescritibilidade do ressarcimento ao erário por atos dolosos de improbidade administrativa. Fórum Administrativo - FA, ano 19, n. 223, p. 55-74, set. 2019.

MELLO, Celso Antônio Bandeira de. Curso de Direito Administrativo. 32. ed. São Paulo: Malheiros, 2015.

NOHARA, Irene Patrícia. Direito Administrativo. 9. ed. São Paulo: Atlas, 2019.

OSÓRIO, Fábio Medina. Direito Administrativo Sancionador. 4. ed. São Paulo: Revista dos Tribunais, 2011.

PELEGRINI, Marcia. A competência sancionatória do Tribunal de Contas: contornos constitucionais. Belo Horizonte: Fórum, 2014.

SILVA, Virgílio Afonso da. O proporcional e o razoável. Revista dos Tribunais, $\mathrm{n}$. 798, p. 23-50, 2002.

SUNDFELD, Carlos Ari. Direito Administrativo para Céticos. São Paulo: Malheiros, 2012. 